\title{
ON LETTING THE LAITY LITIGATE: THE PETITION GLAUSE AND UNAUTHORIZED PRACTICE RULES
}

Everywhere in France today a class of men predominates whom some call lawyers; others, pleaders. So great was the cunning of these men about 300 years ago that not only have they now almost completely overthrown the authority of the public council . . . but they have forced even the princes of the kingdom, and royal majesty itself, to do obeisance to their grandeur.

\section{-François Hotman, Francogallia (1573)}

One does not have to inhale the self-adulatory bombast of after-dinner speeches to affirm that all the interests of man that are comprised under the constitutional guarantees given to "life, liberty and property" are in the professional keeping of lawyers.

- Justice Frankfurter, concurring, in Schware v. Board of Bar Examiners (1957)

Every American jurisdiction licenses the practice of law. ${ }^{1}$ Qualifications for licensure-prescribed sometimes by statute, sometimes by rule of court-typically include graduation from an accredited law school, successful completion of a bar examination, good moral character, and payment of bar association dues. ${ }^{2}$ Unlicensed practice may be punished as contempt, ${ }^{3}$ and also constitutes a crime in many states. Licensure's proponents (mostly lawyers themselves) usually portray it as a consumer protection measure, designed to guard the public against

1 State provisions are collected in J. FISCHER \& D. LACHMANN, UNAUTHORIzeD Practice Handbook 6-110 (1972). In some states, rules against unauthorized legal practice are not commonly enforced. See Rhode, Policing the Professional Monopoly: A Constitutional and Empirical Analysis of Unauthorized Practice Prohibitions, 34 STAN. L. REv. 1, 20 (1981). An attempt by a layperson to enter an appearance on another's behalf might well provoke enforcement in these states, however. In the federal courts, admission to practice is governed by the rules of the relevant court. See, e.g., U.S. SUP. CT. R. 5; FED. R. APP. P. 46.

2 See, e.g., Mich. Comp. LAws ANN. $\S 600.931$ (fees), 600.934 (qualifications for admission to bar; good moral character), 600.937 (educational requirements) (West 1981).

see, e.g., Mich Comp. Laws ANN. $\S 600.916$ (West 1981).

4 See, e.g., Mass. AnN. Laws ch. 221, § 41 (Michie/Law. Co-op. 1974); R.I. GeN. LAWS § 11-27-14 (1956); S.D. CodIfIED LAWS ANN. § 16-16-1 (1979); Wash. Rev. Code ANN. § 2.48.180 (1961). 
fraud and inferior legal craftsmanship. ${ }^{\sigma}$ Most enactments proscribing unauthorized practice, however, make no general provision for the waiver of such "protection" by even the most informed consumer. Clients who surrender their right to advice and representation by stateapproved counsel thus effectively relinquish their right to be advised or represented at all. ${ }^{\mathrm{B}}$

Governmental solicitude for legal consumers might pass without objection if potential advocates varied only in technical proficiency. But they vary in other important ways that are captured only very imperfectly by the concept of "competence." They vary in ideological tilt, in educational and cultural background, in intellectual style, in social class, and in their relationship to the professional legal community. The identity of the advocate shapes the content of the advocacy, and the choice of a representative is effectively a decision about the very essence of one's claim or defense. To the extent, therefore, that licensure restricts the litigant's choice among advocates, it implicates the litigant's interest in defining and controlling the presentation of her case.

Some jurisdictions evince at least a limited recognition of this interest by expressly permitting individuals to reject assistance from the bar and represent themselves in court proceedings. ${ }^{7}$ The Supreme Court has held that for criminal defendants, at least, the right to appear pro se is of constitutional proportions. ${ }^{8}$ The right to appear pro se, however, expands the class from which litigants may select their champions by just one member-the person whom only the proverbial fool would pick.

- See, e.g., Hicks \& Katz, The Practice of Law by Laymen and Lay Agencies, 41 YALE L.J. 69, 71-72 (1931).

- Convicted criminals constitute an exception. See Johnson v. Avery, 393 U.S. 483 (1969) (overturning prison regulation barring assistance from fellow prisoners in preparing habeas petitions).

? See, e.g., 28 U.S.C. $\$ 1654$ (1976) ("parties may plead and conduct their own cases personally or by counsel"); MICH. Comp. LAws ANN. $§ 600.1430$ (West 1981) ("Every person of full age and sound mind, may prosecute or defend civil actions in any court by an attorney, or may, at his election, prosecute or defend civil actions in person."); 42 PA. Cons. STAT. ANN. § 2501 (Purdon 1981) ("(a) Civil Matters-In all civil matters before any tribunal every litigant shall have a right to be heard, by himself and his counsel, or by either of them. (b) Criminal Matters-In all criminal prosecutions the accused has a right to be heard by himself and his counsel."); WIS. SuP. CT. R. 11.02(1) ("Every person of full age and sound mind may appear by attorney in every action or proceeding by or against the person in any court except felony actions, or may prosecute or defend the action or proceeding in person.").

- See Faretta v. California, 422 U.S. 806 (1975). Faretta, a defendant in a state criminal trial, desired to represent himself rather than use the public defender; the California courts refused his request. Id. at 807-10. In reversing, the Supreme Court noted, "Unless the accused has acquiesced in such representation, the defense presented is not the defense guaranteed him by the Constitution, for, in a very real sense, it is not his defense." Id. at 821. 
This concession is insufficiently responsive to the litigant interests at stake. The first amendment, after all, forbids state action that abrogates the right of citizens "peaceably to assemble, and to petition the Government for a redress of grievances." The plain language of that proscription seems to embrace the concerted efforts of a claimant and her advocate to secure redress in the courts.

This Comment will appraise the constitutionality of existing restrictions on unauthorized practice from the standpoint of the client's petition rights. ${ }^{10}$ Special emphasis will be placed on legal services rendered in the context of actual or potential civil litigation-the context that most straightforwardly implicates petition rights. Although prohibitions against the lay practice of nonlitigious law pose serious constitutional and policy issues, these have been ably discussed already. ${ }^{11}$ Even critics of unauthorized practice rules, however, have shied away from urging the deregulation of in-court advocacy. ${ }^{\mathbf{1 2}}$ If their hesitation stems from a perception that courtroom advocacy may well be the last area over which the organized bar would surrender control, ${ }^{13}$ then their reticence may make good sense as a matter of political strategy. It makes less sense as a matter of constitutional doctrine. It is in the courtroom, at the very site where litigants press their grievances

- U.S. Const. amend. I. Most state constitutions contain similar provisions. See Alaska Const. art. I, § 6; Ariz. Const. art. II, § 5; ARk. Const. art. II, § 4; Cal. Const. art. I, § 3; Colo. Const. art. II, § 24; ConN. Const. art. I, § 14; DeL. Const. art. I, § 16; Fla. Const. art. I, § 5; GA. Const. art. I, § 1, I 12; HawaII Const. art. I, § 4; IDAho Const. art. I, § 10; Ill. ConsT. art. I, § 5; KaN. ConsT. Bill of Rights, § 3; KY. Const. Bill of Rights, $\S 1$; LA. Const. art. I, 9 ; ME. Const. art. I, § 15; MD. Const. Dec. of Rights, art. XIII; Mass. Const. Dec. of Rights, art. XIX; MICH. ConsT. art. I, § 3; MISs. Const. art. III, § 11; Mo. ConST. art. I, § 9; MonT. CoNST. art. II, § 6; NEv. CoNST. art. I, § 10; N.H. Const. part I, art. 32; N.Y. Const. art. I, § 9; N.C. ConsT. art. I, § 12; N.D. CoNST. art. I, § 5; Ohio Const. art. I, § 3; OKLA. Const. art. II, § 3; OR. ConST. art. I, § 26; R.I. Const. art. I, § 21; S.G. Const. art. I, § 2; S.D. Const. art. VI, § 4; TENN. Const. art. I, § 23; TEX. Const. art. I, § 27; VT. ConsT. ch. I, art. 20; VA. Const. art. I, § 12; WASH. Const. art. I, § 4; W. VA. Const. art. III, § 16; WIS. Const. art. I, § 4; Wyo. Gonst. art. I, § 21.

10 No argument based on any alleged constitutional right of the advocate to practice law will be advanced.

11 See, e.g., Christensen, The Unauthorized Practice of Law: Do Good Fences Really Make Good Neighbors-or Even Good Sense?, 1980 AM. BAR FouND. RESEARCH J. 159 (providing historical sketch of development of unauthorized practice rules); Rhode, supra note 1 (constitutional analysis of unauthorized practice rules focusing upon due process and first amendment doctrines). Although both of these authors advocate the abolition of unauthorized practice rules, neither focuses on the petitionary interests implicit in the context of litigation.

12 See, e.g., Christensen, supra note 11, at 214-15 ("perhaps only duly admitted lawyers should have the privilege of appearing in court"); Rhode, supra note 1, at 7577 ("in-court representation presents the strongest argument for excluding lay practitioners").

13 See Rhode, supra note 1 , at 76. 
upon the state, that their freedom to press their grievances may most deserve protection.

Part I develops the argument that the petition clause should be read as part of a constitutional framework that seeks to legitimate governmental decisions, including court decisions, by submitting them to a full and open discursive process. The right of individuals to petition the courts provides one device whereby legitimating discussion may be facilitated. Part II describes how unauthorized practice provisions implicate the petition right anatomized in part I. Part III assesses whether licensure may nevertheless be a necessary component of any attempt to vindicate the state's valid interest in protecting the consuming public. It first suggests that a less drastic means analysis be used to evaluate licensure; a certification system is then proposed as both more conducive to legitimate regulatory objectives and less restrictive of client rights. Insofar as licensure is a superfluously drastic technique for achieving permissible regulatory ends, it disserves the legitimating animus behind the first amendment's petition clause, and should be declared unconstitutional.

\section{General Contours of the Petition Right}

For the better part of our country's history, the petition clause languished in juridical oblivion. Although its meaning was hotly debated in other arenas, ${ }^{14}$ it received virtually no judicial elaboration. ${ }^{15}$ Only in the last few decades have the courts begun to define the scope of the petition clause in any serious way. It has become clear, at least, that the petition clause protects grievances addressed to any department $^{16}$ of any sovereign, whether state or federal, ${ }^{17}$ against governmental interference. ${ }^{18}$ In particular, the petition clause protects access to

14 In 1840 the House of Representatives, responding to a tidal wave of petitions demanding the abolition of slavery, adopted a standing rule whereby it would refuse even to accept petitions touching on slavery. John Quincy Adams led a protracted battle against this rule, arguing that it violated the petition clause. Eventually, Adams prevailed, and the rule was rescinded. See J.Q. ADAMS, SPEEch OF JoHN QuincY ADAMS UpON THE Right to PETITION (1969) (reprinting portions of the Congressional debate); D. Smith, The Right to Petition for Redress of Grievances: ConstiTUTIONAL DEVELOPMENT AND INTERPRETATIONS 81-108 (1971).

16 United States v. Cruikshank, 92 U.S. 542 (1875), was apparently the first Supreme Court case in which the right to petition received any substantial discussion. The Court stated, "The very idea of a government, republican in form, implies a right on the part of its citizens to meet peaceably for consultation in respect to public affairs and to petition for a redress of grievances." Id. at 552 . (1972).

${ }_{16}$ See California Motor Transport Co. v. Trucking Unlimited, 404 U.S. 508, 510

${ }^{17}$ See United Mine Workers v. Illinois Bar Ass'n, 389 U.S. 217, 221-24 (1967).

${ }^{18}$ Federal interference with the right to petition state governments comes within 
state and federal courts ${ }^{10}$ and administrative tribunals. ${ }^{20}$

The substantive nature of the petition right nevertheless remains highly obscure. The courts have neither offered a detailed specification of the right's content nor situated it within a larger vision of the first amendment. ${ }^{21}$ Instead, the courts have usually cited the petition clause only alongside invocations of the first amendment's speech and assembly clauses ${ }^{22}$ - a pattern that impedes a clear understanding of the petition right itself. Some account of the right must be supplied, however, if the access to the courts that it affords is to be capable of intelligent realization.

A proposed account of the petition right is sketched below. Section A suggests that the petition clause be read as part of an overall constitutional scheme for the legitimation of governmental action. Section B then examines the scope of the petition right, particularly in the context of litigation.

this prohibition. See Bill Johnson's Restaurants, Inc. v. NLRB, 103 S. Ct. 2161 (1983) (unanimous decision) (construing National Labor Relations Act in light of petition clause). In Bill Johnson's Restaurants, the petition right was held to prohibit the NLRB from halting

[t]he prosecution of a state-court lawsuit . . . unless the suit lacks a reasonable basis in fact or law. . . . The Board's reasonable basis inquiry must be structured in a manner that will preserve the state plaintiff's right to have a state court jury or judge resolve genuine material factual or state-law legal disputes pertaining to the lawsuit.

Id. at 2173.

19 California Motor Transport Co. v. Trucking Unlimited, 404 U.S. 508, 510 (1972).

${ }^{20} \mathrm{Id}$. at 513.

21 The commentators have largely recapitulated this omission. See, for example, T. Emerson, Toward a General Theory of the First Amendment (1963), which devotes no systematic discussion to the petition right. Given Meiklejohn's emphasis on the first amendment's role in protecting political speech, his silence concerning the petition right is even more surprising. See A. MeIKLEJOHN, FreE SPEECH AND Its Relation to Self-Government (1948). The index to the leading casebook on constitutional law, G. Gunther, Cases and Materials on Constirutional Law (10th ed. 1980), contains no entry for the petition right. Nor does Gunther devote a chapter, or a section of any chapter, to the petition clause.

A few writers have nonetheless rushed in where most have feared to tread. See D. SMITH, supra note 14; Note, A First Amendment Right of Access to the Courts for Indigents, 82 YALE L.J. 1055 (1973). For an excellent treatment of the historical antecedents to the petition clause, see Smellie, Petition, Right of, in 12 ENCYCLOPEDIA of THE Social ScIEnces 98 (1933).

${ }_{22}$ See, e.g., NAACP v. Button, 371 U.S. 415, $428-30$ (1963) (expression, association, and petition); see also Thomas v. Collins, 323 U.S. 516, 530 (1945) (rights to freedom of speech, press, assembly, and petition, "though not identical, are inseparable"). 


\section{A. The Petition Clause, the Constitution, and the Problem of Legitimation}

Classical political theorists envisioned the relationship between citizens and government as a "social contract."23 Although theorists have differed regarding the nature of the social compact, ${ }^{24}$ contractual conceptions of government posit its binding force in the acceptance of government by the governed - the sine qua non of legitimacy. ${ }^{25}$ The state can exercise vast powers in the service of chosen ends; the citizenry, in ceding this power to the state, retains the prerogative to make demands concerning the means and ends of its exercise. ${ }^{26}$ In short, a government

${ }^{23}$ See, e.g., T. Hobbes, Leviathan (Dutton ed. 1950) (1st ed. London 1651). Hobbes argued the "Soveraigne Power" is acquired by "Naturall force" or when "men agree amongst themselves, to submit to some Man, or Assembly of men, voluntarily, on confidence to be protected by him against all others." Id. at 144.

See also Locke, An Essay Concerning the True Original, Extent and End of Civil Government, in Social CoNTRACT 1, 56 (E. Barker ed. 1947) ("When any number of men have so consented to make one community or government, they are thereby presently incorporated.").

Social contract theories have long been propounded. For a brief sketch of the development of this genre of political theory, see Barker, Introduction to id. at vii. This conception of government was influential in the framing of the Constitution. See THE FEDERALIST No. 2, at 8 (J. Jay) (J. Cooke ed. 1961) ("Nothing is more certain than the indispensable necessity of Government, and it is equally undeniable, that whenever and however it is instituted, the people must cede to it some of their natural rights, in order to vest it with requisite powers."); see also The Declaration of Independence para. 2 (U.S. 1776) ("[G]overnments are instituted among men, deriving their just powers from the consent of the governed.").

${ }^{24}$ Compare $\mathrm{T}$. HobBes, supra note 23, with Locke, supra note 23 . Hobbes believed that the formation of the contract was necessitated by the "nasty, brutish, and short" conditions of life, see T. HOBBES, supra note 23, at 104, and was maintained by force, id. at 139. Locke, in contrast, envisioned the contract as arising from a "state of nature" characterized by "perfect freedom" and equality of all. See Locke, supra note 23 , at 4 . The commonwealth was formed to preserve property and provide a "common established law and judicature to appeal to," with all of its members thus "in civil society with another." Id. at 50.

${ }^{20}$ See supra note 23. The words "legitimation" and "legitimacy" as used in this Comment refer to whatever norms bind the state in its actions. Different observers have propounded different substantive accounts of these norms. Compare $1 \mathrm{M}$. WEBER, ECONOMY AND Society 212-301 (1978) with J. Habermas, Legrtimation CRISIS 95-143 (1975). This Comment's argument, however, rests primarily on identifying certain minimal conditions of legitimacy and does not rely on any rich or controversial conception thereof.

For an argument that the concept of legitimation is too blunt an analytic instrument to be of much use to social scientists, see Hyde, The Concept of Legitimation in the Sociology of Law, 1983 WIS. L. REv. 379. The alleged demerits of the concept of legitimacy as a tool in empirical social scientific work do not, of course, detract from its value as a normative political ideal.

${ }^{26}$ For a small sampling of pertinent modern political theory, see, e.g., B. ACKERman, Social Justice and the Liberal State (1980); J. Habermas, supra note 25; J. RAWLS, A Theory of Justice (1971); M. WEBER, supra note 25; Hyde, supra note 25. 
accedes to its sovereign status only insofar as it recognizes that its actions must be legitimated. ${ }^{27}$

In practical terms, legitimacy becomes an issue when it is challenged; problems of legitimacy are raised and assessed discursively. A government's claim to legitimacy is therefore premised upon its tolerance of both general and petitionary discussion. ${ }^{28}$

This imperative to tolerance operates in several dimensions. ${ }^{29}$ First, the state should not condition its tolerance on the discussant's adherence to or rejection of any specific perspective or worldview. ${ }^{30}$ Second, the state should avoid interference with the advocacy of any particular opinion or position. ${ }^{31}$ Third, the state should not silence advocates by limiting access to communicative media or forums. ${ }^{32}$ Fourth,

${ }^{27}$ See, e.g., B. ACKERMAN, supra note 26, at 4-7 ("[W]henever anybody questions the legitimacy of another's power, the power holder must respond not by suppressing the questioner but by giving a reason that explains why he is more entitled to the resource than the questioner is." Id. at 4.).

28 Some writers have contended that just results issue from constraints on discussion. See B. Ackerman, supra note 26, at 3-30. The "constraint" that reason imposes on discussion, however, is to be distinguished from the state's forcible suppression of disfavored ideas.

20 The listed dimensions focus on modes of governmental interference with legitimating discussion. From the discussant's standpoint, a statement generally (1) expresses an opinion (2) from some perspective (3) in some forum or medium (4) to some audience that (5) may include the state. These, of course, are simply aspects under which discussion (or its abridgment) may be viewed-not empirically discrete parts of historically embedded discursive acts. Thus a ban on feminist picketing within a one-mile radius of the White House might be seen as primarily implicating any one of the five dimensions. But see infra note 59 and accompanying text.

${ }^{30}$ Cf., e.g., Brandenburg v. Ohio, 395 U.S. 444 (1969) (per curiam) (violation of free speech for state to punish Ku Klux Klan member's abstract advocacy of violence). Also of interest are National Socialist Party of America v. Village of Skokie, 432 U.S. 43 (1977) (per curiam) (staying, pending appeals, a state injunction that forbade Nazis to march in the village, show swastikas, or distribute literature promoting hatred of Jews or others because such restrictions of first amendment rights can be imposed only using "strict procedural safeguards"; $i d$. at 44); Healy v. James, 408 U.S. 169 (1972) (college's decision not to recognize local chapter of Students for a Democratic Society violated members' first amendment rights to the extent the decision was based upon disagreement with the group's philosophies; the college could refuse to recognize the group only if it showed the group failed to comply with campus regulations); Noto v. United States, 367 U.S. 290 (1961) (the "mere abstract teaching" of Communist theory will not sustain a conviction under the Smith Act; rather, there must be clear proof that the individual defendant intends to carry out his organization's violent goals). But $c f$. Scales v. United States, 367 U.S. 203 (1961) (the Smith Act, which makes it a felony to belong to any organization advocating the violent overthrow of the United States, is not unconstitutional under either the fifth or the first amendments).

s1 Cf., e.g., Organization for a Better Austin v. Keefe, 402 U.S. 415 (1971) (overturning prior restraint on literature criticizing real estate broker's activities).

${ }^{32}$ Cf., e.g., Hague v. CIO, 307 U.S. 496, 515 (1939) (plurality opinion) ("Wherever the title of streets and parks may rest, they have . . ., time out of mind, been used for purposes of assembly, communicating thoughts between citizens, and discussing public questions."). 
the state should not interfere with the circulation of disfavored ideas by regulating aspects of social intercourse closely tied to the process of discussion. ${ }^{33}$ Fifth, in case the discursive process generates valid criticisms of the government, some insurance should be provided that the criticisms will be accorded the government's attention.

All five aspects are interrelated. ${ }^{34}$ Tolerance of petitionary activity implies tolerance in the other four dimensions. Abstention from conditioning tolerance upon the content of a speech requires that the state refrain from content-motivated interference with advocacy. Such tolerance, in turn, means that the state may not deny access to forums or proscribe discursive associational activity. To the extent that the first four aspects of discussion are restricted, the potential to present grievances to the state is truncated, and legitimation is compromised.

The first four aspects of governmental tolerance serve purposes besides legitimation, primarily the protection of individual interests. ${ }^{35}$ In the fifth area, which embraces the petition right, the public functions of discussion are paramount. The discursive regulation of governmental activity is deemed valuable for reasons that go beyond the self-interest of the individual petitioner. So far as legitimation is concerned, the rewards of tolerating the private marketplace of ideas are reaped when citizens address their government. The fact or prospect of confronting criticism leads government to govern better. ${ }^{36}$

s3 Cf., e.g., NAACP v. Alabama, 357 U.S. 449, 460-61 (1958) (unanimous decision) ("Effective advocacy of both public and private points of view . . . is undeniably enhanced by group association . . . . [S]tate action which may have the effect of curtailing the freedom to associate is subject to the closest scrutiny.").

34 The Supreme Court's treatment of the first amendment in related cases suggests the interdependence of these elements. See infra notes 67-84 and accompanying text.

ss Governmental tolerance of the discursive process may, for example, serve to promote individual autonomy and self-realization. See Baker, Scope of the First Amendment Freedom of Speech, 25 UCLA L. REv. 964 (1978). Baker, who devotes no discussion to the petition clause, extols a "liberty model" of the first amendment that protects speech "not as a means to a collective good" but rather as "an arena of individual liberty." Id. at 966 . It has often been contended, of course, that permitting individual discursive liberty conduces to the collective good. See infra note 36.

se Thinkers from many different fields and wildly diverse ideological perspectives have agreed that artificial suppression of discussion taints the validity of knowledge. For a small sampling, see P. Feyerabend, Against Method (1978); P. Freire, Pedagogy of the Oppressed (1970); J. Habermas, Knowledge and Human InTerests (1971); T. KuHN, The Structure of Scientific Revolutions (1962); J.S. Mill, On Liberty (1947) (London 1859); J. Milton, Areopagitica (1961) (London 1644); K. Popper, Conjectures and Refutations: The Growth of Scientific Knowledge (1962); R. Unger, Knowledge and Polrtics (1975). Those who read only what can be found in law libraries may prefer Whitney v. California, 274 U.S. 357, 372-80 (1927) (Brandeis, J., joined by Holmes, J., concurring); Gitlow v. New York, 268 U.S. 652, 672-73 (1925) (Holmes, J., joined by Brandeis, J., dissenting); Abrams v. United States, 250 U.S. 616, 624-31 (1919) (Holmes, J., joined by Brandeis, J., dissenting). 
The interrelation of these five dimensions of state tolerance can be seen by examining the entire first amendment, ${ }^{37}$ which embraces each of the five aspects: ${ }^{38}$

\begin{tabular}{c|l} 
First Amendment Freedoms & Spheres of Tolerance \\
\hline Religion & Perspective, Worldview \\
Speech & Opinion, Position \\
Press & Forum, Medium \\
Assembly & Social Aspects of Discourse \\
Petition & Audition of Grievances \\
& by Government
\end{tabular}

The first amendment's role in promoting tolerance of discursive activity links the amendment to issues of legitimacy, a connection frequently emphasized by the Supreme Court. ${ }^{38}$

Traditional canons of judicial procedure also recognize that full discussion is a prerequisite to the legitimate exercise of power. Our judicial system relies on the parties to bring facts to light, to interpret them, to suggest statutory constructions, to propose readings of case law, to tender theories of constitutional right, and to adduce considera-

37 Numerous constitutional provisions facilitate the discursive regulation of governmental action. Many of the constitutional provisions that are so directed, such as those relating to the franchise, make sense only against the backdrop of the general discursive freedom provided by the first amendment. Leaving the first amendment aside, a partial listing would include: U.S. ConST. art. I, \& 5 ("Each House shall keep a Journal of its Proceedings, and from time to time publish the same . . . ."); id. art. I, \& 6 ("for any Speech or Debate in either House, [members of Congress] shall not be questioned in any other place"); id. art. I, $\S 7$ (in case of veto, President's objections and names of members voting for and against override to be entered in journal); $i d$. art. I, $\S 9$ (habeas corpus); id. art. II, $\S 3$ (President "shall from time to time give to the Congress Information of the State of the Union"); id. art. IV, $\S 4$ ("The United States shall guarantee to every State in this Union a Republican Form of Government . . . ."); id. art. VI ("no Religious Test shall ever be required as a Qualification to any Office or public Trust under the United States"); $i d$. amend. IV (warrants must "particularly describ[e] the place to be searched, and the persons or things to be seized"); $i d$. amends. V \& XIV (due process); $i d$. amend. VI (criminal defendants have right to public trial, to be informed of charges, to confront opposing witnesses, to compulsory process, and to assistance of counsel); $i d$. amend. IX ("The enumeration in the Constitution, of certain rights, shall not be construed to deny or disparage others retained by the people."); $i d$. amend. XIV (equal protection); id. amend. XV (voting rights may not be abridged "on account of race, color, or previous condition of servitude"); $i d$. amend. XIX (voting rights may not be abridged "on account of sex"); id. amend. XXIV (poll taxes prohibited in federal elections); $i d$. amend. XXVI (for citizens over eighteen, voting rights may not be abridged "on account of age").

s8 The Supreme Court has not chosen to associate clauses of the first amendment with aspects of tolerance for discussion in the manner indicated here. It has pursued all five themes of discursive liberty within the first amendment's framework, however. See supra notes 30-33 and accompanying text.

so See, e.g., Brown v. Hartlage, 456 U.S. 45, 52-53 (1982); First Nat'l Bank v. Bellotti, 435 U.S. 765, 776-77 (1978); Elrod v. Burns, 427 U.S. 347, 356-57 (1976) (plurality opinion); Thomas v. Collins, 323 U.S. 516, 529-30 (1945). 
tions of public policy. Judges, in response, do not merely announce their decisions, but also seek to justify them by addressing whatever pertinent arguments the parties have made. ${ }^{40}$

Inasmuch as both the Constitution and courtroom usage reflect a preference for influencing the sovereign's behavior through a process of rational discussion, the hypothesis that the petition clause plays a legitimating role represents a promising framework within which to explicate the right of access to the courts protected by the petition clause.

\section{B. Exercise of the Petition Right and the Role of the Courts}

A petition will typically invoke legal or political norms quite distinct from the norm that requires the state to tolerate discussion. ${ }^{41}$ Sound government will not be furthered by requiring the state to grant redress to petitions that invoke these norms invalidly or that call upon the state to act in an illegitimate manner. The ship of state cannot plot a new course every time someone performs the physical act of delivering a petition. Even where the government entertains, but fails to redress, a valid grievance, it is the underlying interest the grievant asserts, and not the right to be heard concerning that interest, that the government violates. The first amendment by itself, in this sense, bestows on the petitioner no right to prevail. ${ }^{42}$

These observations suggest a more general feature of the petition right: just as the right to petition bestows no right to prevail, so too the absence of a right to prevail does not obviate the right to petition. ${ }^{43}$ The

10 Where our judicial system does terminate debate, it is usually due to a perception that the questions in controversy have already been subjected to a relatively full discussion. When this condition is not met, constraints on further debate are often lifted. See, e.g., Restatement (SECOND) of Judgments $\S 88$ (1982) (collateral estoppel inapplicable if party against whom it is asserted lacked full opportunity to litigate issue in earlier proceeding). Limitations on discussion are also employed, at times, to protect the discursive process from abuse. See, e.g., FED. R. Grv. P. 12(f) ("redundant, immaterial, impertinent, or scandalous matter" may be stricken from pleadings).

11 A litigant, of course, may petition the courts claiming a prior violation of her petition rights. This, however, is an exceptional case and involves two distinct petitionary episodes: one in which the right was purportedly abridged and a second in which the litigant asserts that her petition rights were violated by the first abridgment.

12 During the ratification debates on the first amendment in the House of Representatives, it was proposed to include a right to instruct the legislature. The proposal failed. See 1 ANNALS OF Gong. 759-68 (J. Gales ed. 1789).

is The Supreme Court has indicated that baseless litigation may be prohibited consistently with the petition clause but has required that the plaintiff's case be not merely baseless but a sham. See Eastern R.R. Presidents Conf. v. Noerr Motor Freight, Inc., 365 U.S. 127, 144 (1961). A plaintiff would presumably be shamming if she brought a claim not for the purpose of pressing a grievance but solely in order to employ the apparatus associated with litigation, see infra note 56 and accompanying text, to harass someone. The baselessness of her claim might be evidence of such a 
petition clause would otherwise require only that the state "tolerate" the set of grievances it ultimately chose to favor with redress-a demand whose satisfaction is close to automatic.

If the right to petition is to be meaningful, it must mandate some minimum level of state receptivity to citizens' grievances. Any honest effort to preserve the petition right must reckon with the fact that the government can effectively avoid taking cognizance of grievances by either of two methods: it can directly impede petitionary behavior or it can hide from would-be petitioners. Of these two methods, the latter may be the more insidious. To jail dissidents is forthrightly to abjure any claim to legitimacy, whereas to leave the phone off the hook simply conveys the impression of a hardworking government already overburdened with the cares of statecraft.

If petitioning the government is to be possible at all, the state must, at a minimum, accept delivery of petitions ${ }^{44}$ - a duty that probably implies recognizing or maintaining forums that have been associated with governmental redress of grievances for time out of mind, just as access to traditional "public forums" enjoys protection in the free speech context. ${ }^{45}$ Perhaps, alternatively, the state should be free to create whatever institutions it pleases for accepting petitions, so long as it grants access to these institutions in a nondiscriminatory manner. ${ }^{46}$ In either case, the institutions must not obstruct delivery of petitions based on the unsuitability of their content if they are to meet their responsibilities as petitionary forums.

It might nonetheless be proposed that petitionary responsibilities need not be met when a petition is addressed to a governmental department that lacks the power to resolve the underlying grievance. Any attempt to delimit the petition right according to the power of the peti-

purpose. Likewise, the tort of abuse of process can presumably coexist with the petition clause.

14 The rules of the House of Representatives provide that all petitions from citizens presented by members to the clerk are entered in the House Journal and published in the Congressional Record. See RuLES OF THE House OF REPRESENTATIVES, 86TH CoNG., 2D Sess. 478-81 (1961).

15 See Cantwell v. Connecticut, 310 U.S. 296, 303-04, 306-07 (1940) (first amendment permits regulation, but not foreclosure, of use of public forums; regulation may not pertain to content of the speech); Hague v. CIO, 307 U.S. 496, 515-16 (1939) (plurality opinion) (use of public forums may be regulated, but "must not, in the guise of regulation, be abridged or denied"). For a discussion of free speech problems in the public forum context, see Kalven, The Concept of the Public Forum, 1965 SuP. CT. REV. 1, 10-32.

48 Cf. Police Dep't v. Mosley, 408 U.S. 92 (1972) (holding unconstitutional a Chicago ordinance regulating picketing "by classifications formulated in terms of the subject of the picketing" because government may not select users of forum on basis of content of speech). 
tioned department, however, soon encounters insuperable difficulties. ${ }^{47}$ For any given grievance, almost no governmental authority is wholly without power to act on it in some manner. The legislatures, for example, are empowered to enact statutes and to initiate amendments to the Constitution; ${ }^{48}$ there may well be no grievance that they lack the power at least to participate in redressing. The same is true of the executive branches, ${ }^{48}$ which have the duty to see to the law's faithful execution ${ }^{50}$ and to recommend to the legislatures such measures as are deemed necessary and expedient. ${ }^{81}$ The courts, of course, play an expansive role in the substantive development of the law, as well as in defining the scope of their own authority. ${ }^{52}$ It is thus difficult to identify any domain of human conduct in which any of these governmental departments would be utterly powerless to intervene.

To be sure, the state has only finite quantities of time and money to spend on auditioning grievances or on facilitating access to itself, and no amount of governmental generosity with its time or money can guarantee that officeholders will actually listen to grievances attentively or thoughtfully. ${ }^{\text {ss }}$ A distinction can be drawn, however, between the state's acceptance and pursuit of petitions. Acceptance of a complaint does not entail an inquiry into its validity, while pursuit of a complaint does entail such an inquiry. Concededly, one feels reassured about the legitimacy of a government that accepts grievances partly from one's sense that the public fact of a petition's delivery will sometimes pressure the state into pursuing the grievance. A little nagging, that is, may goad the state into acting responsibly. Responsibility, however, does not consist

42 In cases where the authority of the petitioned branch can fairly be debated-that is, in all the interesting cases-the proposed restriction generates intolerable consequences. The restriction implies, for example, that suitors in federal court would not be protected if they were ultimately found to lack standing under article III, or to have raised a political question.

${ }^{48}$ See, e.g., U.S. ConST. art. V; PA. Const. art. II.

4 See, e.g., U.S. ConST. art. II; Colo. Const. art. IV, $\S \S 2,8$.

so See, e.g., U.S. ConST. art. II, $\S 3$, cl. 4; IIL. ConST. art. V, $\S 8$.

s1 U.S. ConsT. art. II, $\S 3$, cl. 1.

62 See Marbury v. Madison, 5 U.S. (1 Granch) 137 (1803).

5s Perhaps it is for reasons such as these that the courts have not interpreted the petition clause to impose a state duty to supply an attorney to civil litigants or to minimize access costs. In areas such as divorce, in which the courts have a monopoly on remedial power, the Supreme Court has held on due process grounds that states may not abridge indigent litigants' access to the courts based solely on their inability to pay a filing fee. See Boddie v. Connecticut, 401 U.S. 371 (1971). But see Ortwein v. Schwab, 410 U.S. 656 (1973) (permitting $\$ 25$ filing fee as condition for review of denial of welfare benefits where alternative avenues for appeal are available); United States v. Kras, 409 U.S. 434 (1973) (permitting $\$ 50$ filing fee in voluntary bankruptcy proceeding). Although these cases were not decided on petition clause grounds, they do not suggest strong sympathy on the Court's part for the problems of poor civil litigants. 
in letting all suitors for the state's favors talk until they tire or in devoting equal time to every petition. Some grievances are more complex than others. Moreover, the state should be free to devote extended consideration to claims that seem especially deserving of such consideration. $^{\text {.4 }}$

Assuming then that the state has no absolute duty originating in the first amendment to allow any particular individual to be involved in its discretionary deliberative processes, the question arises how far the petition clause protects the rights of persons whose voluntary discursive contribution the state chooses, or is bound by provisions other than the first amendment, to solicit. This question assumes special importance as regards litigation. ${ }^{50}$ Unlike pleas dispatched to legislators or executive officials, a petition addressed to a court or quasi-judicial tribunal of competent jurisdiction normally triggers an official process whereby legal norms are enforced. ${ }^{86}$ The parties forthwith become players in the resolution of the case-in the pursuit, that is, of the plaintiff's grievance. Although the courts may be affirmatively bound to accept the plaintiff's complaint-along, perhaps, with the defendant's answer, petitions to intervene, amicus briefs, and so forth-nothing in the petition clause, standing alone, seems to guarantee that these documents will precipitate, or play a role in, a trial. ${ }^{57}$

The Supreme Court has nevertheless clearly indicated that the petition right embraces litigious activity. ${ }^{88}$ From the standpoint of promoting legitimation, this makes good sense. Voluntary citizen participation in deliberative processes contributes to the perceived legitimacy of the state's conduct, so that one properly desires some assurance that the participants are in fact free to express their views. No sound reason exists for permitting the state to present a false appearance of receptiv-

o4 It is possible that the state's selection of cases "deserving of consideration" would be made in a manner unduly restrictive of petitionary freedom. Arguably, the doctrines of standing and justiciability presently engender this effect. See, e.g., Valley Forge Christian College v. Americans United for Separation of Church and State, Inc., 454 U.S. 464 (1982) (denying standing to persons challenging HEW's gratuitous conveyance of property to a religious college); Simon v. Eastern Ky. Welfare Rights Org., 426 U.S. 26 (1976) (denying standing to persons unable to obtain medical services at hospitals granted federal tax benefits; plaintiffs were challenging revenue rulings that defined the hospitals as "charitable" institutions qualifying for such benefits).

os See infra notes 56-57 and accompanying text.

se The filing of a complaint alters the legal status quo insofar as, for example, the plaintiff becomes entitled to judgment if the defendant files no answer. It also creates powers in the parties-subpoena powers, for example-that are absent in other petitionary contexts. course.

67 Other constitutional and statutory provisions may afford this guarantee, of

${ }^{88}$ See, e.g., United Mine Workers v. Illinois Bar Ass'n, 389 U.S. 217 (1967); NAACP v. Button, 371 U.S. 415 (1963). 
ity to citizens' views. On the contrary, any governmental body that reaps the political benefits from its apparent eagerness to entertain open, participatory debate on its actions and policies should deliver the reality of debate to an extent at least equal to that of the appearance. In a judicial system that purports to let the parties present their cases as they see fit, therefore, the parties' right actually so to present their cases should receive the first amendment's protection.

Apart from the special character of the forum, petitionary speech does not differ in its grosser aspects from ordinary speech. Consequently, any technique available to the government for suppressing expression in the private marketplace of ideas may prove equally effective in the petitionary domain. The state, for example, might deny access to petitionary forums to the proponents of disfavored ideas, or might abridge the grievant's right to associate for petitionary purposes, perhaps by permitting grievants to enlist the aid only of persons whom the state certified as right-minded. ${ }^{5 \theta}$ In practice, states have chosen to prohibit unlicensed persons from acting as courtroom advocates. Part II describes how the right to petition one's government is implicated by these proscriptions.

\section{How Prohibitions Against Lay Advocacy Impede Litigants' Petition Rights}

Discursive legitimation of judicial decisions might be compatible with rules excluding the laity from the advocacy function in a world where lawyers were licensed through a pure lottery with free tickets. In such a world, the legal community might be a microcosm of society; at the least, its members would be no less likely than nonmembers to understand and present faithfully their clients' claims. Unauthorized practice rules, however, help to make ours a world where candidates for the

${ }^{89}$ This coincidence of methods whereby private and petitionary expression can be repressed may be responsible for the courts' habit of compound citation-their tendency, that is, to see anti-petitionary measures as violating the petition clause and freedom of association or the petition clause and freedom of speech. See supra note 22 and accompanying text. Neither the similarity of the techniques for abridging private and petitionary speech nor a pattern of indecisive citation, however, should obscure the distinction between the general suppression of ideas and their repression in the specifically petitionary context. When this distinction has made a difference in the outcome, the Supreme Gourt has recognized it and has treated the general concomitants of petitionary endeavor as implicated by the petition clause itself. Consider, for example, the finding by Justice Roberts in Hague v. CIO, 307 U.S. 496, 512-13 (1939), that speech and association incident to the assertion of federally created rights constitute aspects of petitionary endeavor and hence fall within the protection of the fourteenth amendment's privileges and immunities clause. 
bar are first selected from a small segment of the population ${ }^{60}$ and then subjected to at least three years of intensive acculturation to professional norms. ${ }^{61}$ By the time most students emerge from the legal education system, their worldview is no longer representative of even the select pool from which they were chosen. ${ }^{62}$ The imperatives of "competence" exact a price in breadth of outlook.

Professional legal norms, reflecting the biases of the education process, are not neutral with respect to the spectrum of claims that clients may wish to assert. Grievances not readily accessible to treatment via existing doctrinal techniques are likely to be forced into more accepted molds or abandoned altogether. Some clients may come to attorneys desiring such remolding of their claims. Others may desire to press issues as yet incompatible with legal norms, and may prefer to refrain from recasting them in conventional doctrinal terms or from pressing other points more likely to yield a favorable verdict in the particular case.

The bias of legal norms would be harmless enough if advancing a client's claim were a purely technical matter, involving only the mechanical application of formal rules of which lawyers, by dint of training and experience, could claim a special mastery. The treatment of some matters, such as name changes and uncontested divorces, may sometimes approximate this caricature of the advocate's role. ${ }^{63}$ Even in such cases, however, a client may view the matter as anything but rou-

60 See infra notes 102-05 and accompanying text.

61 For a general discussion of the role of educational institutions in preserving hierarchical structures in the division of labor, see S. BOWLES \& H. GINTIS, SCHOOLING IN Capitalist AMERIGa: EDUCational REFORM aND THE Contradictions of Economic Life (1976); R. SennetT \& J. Cobb, The Hidden Injuries of Class 53-118 (1973).

For a critical treatment of legal education as a mechanism of professional acculturation, see ARIstophanes, Clouds. Modern criticism of legal education as a mechanism for preservation of hierarchy and of acculturation to deleterious professional norms is expressed in Kennedy, Legal Education and the Reproduction of the Hierarchy, 32 J. Legal Educ. 591 (1982).

62 See Unger, The Critical Legal Studies Movement, 96 HARv. L. REv. 563, 669 (1983) ("IT]he real message of the curriculum is . . . that a mixture of low-level skills and high-grade sophistic techniques . . . is all there is-all there is and can be-to legal analysis and, by implication, to the many methods by which professional expertise influences the exercise of state power."). Unger's is a polar view, but it captures a real aspect of the subject. Compare Veblen's remarks: "The lawyer is exclusively occupied with the details of predatory fraud, either in achieving or in checkmating chicanery, and success in the profession is therefore accepted as marking a large endowment of that barbarian astuteness which has always commanded men's respect and fear." $T$. Veblen, The Theory of the Leisure Glass 156 (1953).

6s The hardiest partisans of prohibitions against unauthorized practice, however, are themselves the first to insist that such treatment disserves client interests. See, e.g., Letter from James W. Robinson to Chief Justice Warren E. Burger (June 19, 1974), reprinted in 39 Unauth. Prac. News 51 (1974). 
tine. For some clients, true vindication of their claims would require the exercise of creativity and sympathy beyond the scope of technical legal devices. ${ }^{64}$ The problems of women seeking divorce, for example, are often not so much expressed in the divorce proceedings as they are refashioned to suit courtroom exigencies. ${ }^{65}$

Whether a litigant desires to pursue an unusual or a routine matter, the restructuring or wholesale abandonment of her claim shields the judicial system from confronting the litigant's conception of it. By thus restricting a true petitionary process, the bar's monopoly on advocacy works to undermine the legitimacy of legal doctrine in the eyes of the citizens it regulates. ${ }^{68}$

Although the Supreme Court has never been presented with a litigant who challenged attorney licensure on the grounds of a claimed petition right, ${ }^{6 z}$ the Court's treatment of several related cases clearly

64 In a recent survey, $21 \%$ of all respondents felt that "[1]awyers don't really try to understand what their clients want"; $36 \%$ felt that "[l]awyers do not care whether their clients fully understand what needs to be done and why"; $50 \%$ felt that "[I]awyers are generally not very good at keeping their clients informed of progress on their cases"; and $44 \%$ felt that "[a] person should not call upon a lawyer until he has exhausted every other possible way of solving his problem." B. CURRAN, The LEGAL NEeDs of THE PUBLIC 228, 230 (1977).

${ }_{65}^{65}$ [T] The most extreme precautions must be taken to avoid . . . an unfortunate demonstration on your client's part. She must be made to understand the serious, indeed, the catastrophic results which may follow an exhibition on her part. She should comport herself in a ladylike manner on the witness stand if for no other reason than that it is her duty to do so: but she must be made aware of the grave consequences if she fails to do it. Therefore, you should impress upon her the critical necessity for maintaining at all times a civil and orderly demeanor. This is not to say that she is obliged to be calm. That may be too much to ask; in some circumstances, being calm may even be self-defeating. There is such a thing as excessive composure. But she must be civil.

C. Rothenberg, Matrimonial Litigation: Strategy and Techniques 11-13 (1972).

${ }^{66}$ The Supreme Court has shown an awareness that the litigant's contribution has a value not just for herself but for society at large:

The NAACP is not a conventional political party; but the litigation it assists, while serving to vindicate the legal rights of members of the American Negro community, at the same time and perhaps more importantly, makes possible the distinctive contribution of a minority group to the ideas and beliefs of our society.

NAACP v. Button, 371 U.S. 415, 431 (1963) (emphasis added). The benefits accrued from a multiplicity of voices are recognized in many ways. See supra note 36.

${ }^{67}$ But see Silverman v. Browning, 414 F. Supp. 80 (D. Conn.) (three-judge panel) (rejecting equal protection and due process challenges to exclusion of appearance by litigant's pro hac vice lawyer in state claim), affd mem., 429 U.S. 876 (1976); Norfolk \& Western Ry. v. Beatty, 400 F. Supp. 234 (S.D. Ill.) (three-judge panel) (finding no constitutional difficulty with prohibition of appearance by litigant's pro hac vice lawyer in FELA action but citing no particular constitutional provision), affd mem., 423 U.S. 1009 (1975). These decisions did not involve any explicit first amend- 
identifies the petitionary interests involved.

In Faretta $v$. California, ${ }^{68}$ the Burger Court recognized that criminal defendants enjoy a right to conduct their defense without a lawyer's aid. Although the Court devoted considerable attention to the history and language of the sixth amendment's guarantee of counsel, its opinion also evinced a general concern for the rights of litigants to manage their own cause:

It is true that when a defendant chooses to have a lawyer manage and present his case, law and tradition may allocate to the counsel the power to make binding decisions of trial strategy in many areas. This allocation can only be justified, however, by the defendant's consent, at the outset, to accept counsel as his representative. An unwanted counsel "represents" the defendant only through a tenuous and unacceptable legal fiction. ${ }^{69}$

Noting that some defendants might mount a better case than a lawyer would, the Court added that to impose an unwanted lawyer on a defendant "can only lead him to believe that the law contrives against him." In any case, the Court observed, "[t]he defendant, and not his lawyer or the State, will bear the personal consequences of a conviction. It is the defendant, therefore, who must be free personally to decide whether in his particular case counsel is to his advantage."71

Faretta's emphasis on the sixth amendment raises the question whether a constitutional right to appear pro se extends to civil litigants. ${ }^{72}$ The Supreme Court has not had occasion to address this question directly, ${ }^{73}$ but no sound basis appears on which to limit Faretta's rationale to criminal cases. A civil litigant, no less than a criminal de-

ment claims. Moreover, the differences in outlook as between two lawyers may be too slight clearly to implicate the content of the litigant's petition. The contrast between lay and lawyer attitudes is starker.

68422 U.S. 806 (1975).

69 Id. at $820-21$.

zo Id. at 834 .

71 Id.

72 At least one commentator has expressed doubts that any constitutional pro se right exists in civil controversies. See Kaufman, The Right of Self-Representation and the Power of Jury Nullification, 28 CASE W. REs. L. REv. 269, 271 n.7 (1978).

73 No case presenting this question is soon likely to arise. Most jurisdictions now grant the right to appear pro se either by constitution or by statute. See J. Fischer \& D. LACHManN, supra note 1, at 20-22. Faretta, moreover, arose through the defendant's attempted rejection of state-appointed counsel-a resource seldom proffered to civil litigants. If anything, the argument for freedom to conduct one's own case seems stronger in civil actions, inasmuch as indigent civil litigants, unlike their criminal counterparts, have no recognized constitutional right to an attorney provided by the state. 
fendant, "will bear the personal consequences" of a defeat, and to thrust a lawyer upon a civil litigant seems equally likely to "lead him to believe that the law contrives against him."

The recognition of a right to proceed pro se undermines the rationales usually given for unauthorized practice rules. ${ }^{74}$ Still graver questions for lawyer licensure are posed when the right to appear pro se is considered together with a series of Supreme Court decisions upholding the public's first amendment right to associate for the purpose of petitioning the courts.

The leading case in this line is NAACP v. Button. ${ }^{75}$ At issue in Button was a Virginia unauthorized practice statute making it illegal for an attorney to accept employment or compensation from any organization unless that organization was a party to, or had a pecuniary stake in, ongoing judicial proceedings. ${ }^{76}$ The same statute forbade any organization to solicit business for any lawyer. ${ }^{77}$ The NAACP was engaged in a program of financing and promoting civil rights litigation that ran afoul of both provisions. It maintained a legal staff, which it paid on a per diem basis to handle claims on behalf of nonmembers. It also encouraged nonmembers to bring claims, by disseminating bulletins and undertaking petition drives that prompted public meetings, to

74 Unauthorized practice rules are purportedly justified by the need to protect consumers of legal services. See infra notes 85-86 \& 92-93 and accompanying text.

One may reasonably suppose that few persons who make the considered choice to proceed without a lawyer would be careless enough to choose a lay advocate less intelligent, industrious, or articulate than themselves. Rational civil litigants might sometimes pick a less competent advocate if their opportunity costs in appearing pro se, less the cost of the advocate, exceeded the value of their claim, discounted by the reduced probability of a favorable decision. It is difficult to speculate on how often this situation might arise. But, by use of marketplace analogies, it is easy to see that a litigant's choice of less costly but potentially less competent counsel would be natural. See infra note 108 and accompanying text.

In the normal marketplace of goods, consumers usually have a broad choice among substitute goods at a range of prices. They can buy designer originals or off-the-rack apparel, Rolls Royces or Chevy Chevettes, filet mignon or rump roast. The consumer, the one who must pay for the good and endure its faults, makes whatever trade-offs are necessary between price and quality. Evidently, many consumers find the best value with goods that are of less than the highest quality. Similarly, a litigant's choice of a less competent but less expensive legal representative simply constitutes a conscious and efficient allocation of human resources, from which there is no reason to "protect" the consumer. Indeed, the open marketplace itself should provide protection greater than that now provided to consumers seeking cheaper legal representation since, if lay practice were not proscribed, one would expect lay practitioners to possess more experience than nonpractitioners and hence to prevail more often than the ordinary pro se litigant.

For a discussion of the factors that shape an economically rational litigant's decision whether to litigate, see R. POSNER, ECONOMIC ANALYsIS of LAW $\S \S 21.4,21.7$ 21.8 (2d ed. 1977).

${ }_{76} 371$ U.S. 415 (1963).

${ }^{78} I d$. at $423-27$.

77 Id. 
which the NAACP then invited its legal staff. The Supreme Court held that the Virginia statute improperly impinged upon the expressive, associative, and petition rights of NAACP members. ${ }^{78}$

Any hope on the part of the organized bar that Button's holding could be confined to nonprofit organizations of an avowedly political character ${ }^{79}$ was soon dashed in a series of decisions upholding the right of union members to associate for the purpose of securing legal assistance. ${ }^{80}$ As a last line of defense, proponents of licensure have argued that the NAACP's activities in Button did not include the practice of law in the customary sense. ${ }^{81}$ This "distinction" begs the question, for the issue is precisely whether there is any plausible account of the Button Court's concern for the first amendment rights of litigants that does not also implicate the choice of an advocate.

The specific conduct protected by Button was association by nonlawyers with prospective litigants, undertaken in order to facilitate litigation. The NAACP did not limit its activities to the financing or the technical expediting of civil rights litigation; rather, it actively undertook to educate segments of the lay population regarding the availability of legal claims. ${ }^{82}$ Widespread hostility to civil rights actions in Virginia necessitated the NAACP's program of bringing clients together with advocates disposed to treat their claims sympathetically. As the Court noted, "Lawsuits attacking racial discrimination, at least in Virginia, are neither very profitable nor very popular. They are not an object of general competition among Virginia lawyers; the problem is rather one of an apparent dearth of lawyers who are willing to undertake such litigation."8s The Court thus recognized that unless litigants had access to advocates who were friendly to their claims, the right to petition the courts would be hollow.

The NAACP's role as intermediary in Button does not limit the

78 Id. at $428-30,437$.

70 See Christensen, supra note 11, at 199; see also R. Hetlage, Address to the Northeastern Regional Conference on the Unauthorized Practice of Law, May 3, 1974, reprinted as Hetlage, U.S. Supreme Court Decisions During the Past Decade Affecting the Field of Unauthorized Practice of Law, 39 UNAUTH. PRAC. News 17 (1974); Cedarquist, Lawyers at the Crossroads-Profession or Trade?, 31 UNAUTH. PRAC. NEws 79 (1966).

so Group legal service arrangements were upheld in United Transportation Union v. State Bar, 401 U.S. 576 (1971); United Mine Workers v. Illinois State Bar Ass'n, 389 U.S. 217 (1967); Brotherhood of R.R. Trainmen v. Virginia ex rel. Virginia State Bar, 377 U.S. 1 (1964). Like Button, these cases relied, to some extent, upon associational, as well as petitionary, interests; however, a litigant's choice among advocates is clearly implicated throughout all of the cases.

${ }^{\text {s1 }}$ See Hetlage, supra note 79, at 17, 20.

82 See Button, 371 U.S. at 419-22.

ss Id. at 443 (footnote omitted). 
applicability of the case to intermediary arrangements. The NAACP's role instead dramatizes the associative interests that have always been present in the traditional, unmediated relationship between advocate and client. It would be anomalous if a client's right to receive information about potential claims were stronger when such information came from persons not serving as the client's ultimate representative than when directly supplied by the representative herself. It would likewise be anomalous if a client's right to associate with a representative favorably disposed toward her claim depended on the right of the client and representative to associate with some intermediary. ${ }^{84}$

Thus, when only licensed practitioners are involved, the litigant's right to control her case extends to the initial stage at which an attorney is chosen. The question Button poses for defenders of licensure is on what theory the scope of this right may be constricted to a choice among advocates selected by the state.

One possible answer is that none of the client's interests are implicated where the state designates a group of persons who are exclusively entitled to enter appearances, as distinct from giving informal pretrial advice. The existence of the pro se right precludes this answer. Another possible answer is that permitting advice outside the formal judicial process at a stage when legal action has not yet formally commenced poses slighter dangers to clients' interests than would deregulated incourt representation. This explanation of licensure's restriction of choice among advocates is also unsatisfactory. The citizen's first amendment right to petition for a redress of grievances cannot be confined to those grievances that assume a form believed by the state to be in the litigant's best interest, nor is the right to associate for petitionary purposes contingent on a promise by the citizen to associate only in ways the state considers wise. The very real dangers of fraud, abuse, and incompetence in legal representation go not to the urgency of the litigant's interest in free choice, but rather to the question of what measures a state may take to curb abuse without improperly abridging the litigant's petition rights.

s4 Indeed, it was the very presence of such an intermediary to which the state objected in Button. 


\section{ATtorney Licensure Versus Less Drastic Regulatory Devices}

Any man we're ready to sting, in order our income to double. Stingless drones are among us too, who without taking trouble

Devour what others earn. 'Tis this that grieves us soreThat men who evaded soldiering, who never wielded spear or oar,

Should with hands unblistered and soft carry off our revenue.

In future be this the rule: You carry no sting? No obols for you.

-Aristophanes, Wasps

The four principal arguments advanced in favor of licensure are first, that it preserves courtroom decorum; second, that it aids in the discipline of attorneys who engage in unethical practices; third, that it protects the legal industry from the ravages of destructive competition; and fourth, that it protects consumers against incompetence. ${ }^{85}$ These justifications reflect the dual character of legal services. On the one hand, legal services play a pivotal role in preserving the rule of law in our society; this perspective suggests that the delivery of such services should be subject to standards different from those applied to other market commodities. ${ }^{88}$ The first two rationales for licensure seem to stem from this desire to maintain the integrity of the judicial process. On the other hand, the delivery of legal services can be viewed as a purely economic transaction; this perspective implies a predominant concern for consumer satisfaction and welfare. The third and fourth rationales for licensure appear to be designed to regulate the market for legal services in a manner consistent with these concerns.

It is not immediately evident which of the four purposes provides the primary impetus for existing unauthorized practice rules. One possible method of divining the purpose of the rules is to examine their promulgating source. Market regulation is typically a legislative function, whereas the judiciary is a plausible source of rules protecting the soundness of the adjudicative process. If, therefore, one wished to know what purposes a state's unauthorized practice provisions sought to fur-

ss See, e.g., Hicks \& Katz, supra note 5, at 70-72.

so It does not follow that these standards should be more than usually stringent, however; concern for petitionary autonomy may suggest that these standards should be less stringent. 
ther, one might naturally look to the provenance of the state's rules. In fact, however, this strategy affords little clarification.

Admission to state bars is often governed by judicial decisions or rules of court. ${ }^{87}$ Even when legislatures do enact licensure measures, state courts have commonly held, on separation of powers grounds, that the regulation of legal practice is an intrinsically judicial function, and that although the legislature may assist the judiciary in its performance, the legislature cannot authorize practice where the judiciary has proscribed it. ${ }^{88}$ The rationale typically supplied for this result is that attorneys are officers of the court, and the judiciary is therefore necessarily empowered to prescribe minimum character and educational requirements for persons seeking to practice before it. ${ }^{80}$ This theory affords little justification, however, for unauthorized practice rules reaching advice on claims that cannot, or need not, be litigated in state courts.

If, however, licensure is seen as ordinary economic legislation, then no clear reason appears why unauthorized practice rules, or the power to enact them, should follow jurisdictional lines in our federal system. The question might arise, for example, whether state requirements making entry into the profession unduly burdensome may run afoul of the dormant commerce clause ${ }^{80}$ or whether federal decisions to permit nonlawyers to practice in certain specialized federal forums may preempt state regulation of practice in those specialties. ${ }^{81}$

${ }^{87}$ See J. Fischer \& D. LACHMANN, supra note 1, at 3.

88 An exception is New York, which vests primary control in the legislature. See In re Cooper, 22 N.Y. 67 (1860). The general rule is illustrated by Opinion of the Justices, 289 Mass. 607, 612, 194 N.E. 313, 316 (1935):

It is inherent in the judicial department of government under the [Massachusetts] Constitution to control the practice of law, the admission to the bar of persons found qualified to act as attorneys at law and the removal from that position of those once admitted and found to be unfaithful to their trust. While the judicial department cannot be circumscribed or restricted in the performance of these duties, appropriate and essential assistance in discharging them may be afforded by the enactment of statutes.

89 For an argument that the judiciary ought to confine itself to measures necessary to preserve the dignity of the bar, leaving the protection of the public to the legislature, see Comment, Control of the Unauthorized Practice of Law: Scope of Inherent Judicial Power, 28 U. CHI. L. REv. 162 (1960). The traditional notion that judicial power over the practice of law derives from the need to preserve decorum at the bar may operate to deter the judiciary from developing more complex or innovative regulatory measures, which might present too strong an impression of judicial meddling in social policy.

${ }^{80}$ But see Norfolk \& Western Ry. v. Beatty, 400 F. Supp. 234 (S.D. Ill.) (threejudge panel), affd mem., 423 U.S. 1009 (1975), in which a commerce clause claim appears to have been rejected.

פ1 For example, 26 U.S.C. $\$ 7452$ (1976) provides: "No qualified person shall be denied admission to practice before the Tax Court because of his failure to be a member of any profession or calling." See also U.S. TAx CT. R. PRAC. \& P. 200(a)(3) 
In short, unauthorized practice provisions look sometimes like market regulations, at other times like rules of judicial procedure.

Despite their dual nature, inquiry into the purposes of unauthorized practice rules can nonetheless progress if one notes that, regardless of the promulgating authority, not all four proposed purposes for such rules deserve to be taken equally seriously. The contention that these rules are necessary to preserve order in the courtroom, for example, presumably rests on the supposition that lawyers as a group comport themselves more decorously than laypersons-a queer hypothesis. Lay breaches of courtroom etiquette, in any event, could readily be dealt with by the same means used against noisesome lawyers: admonition by the court or citation for contempt. The same is true of ethical breaches; measures used to restrain and discipline attorneys would be equally effective against the laity.

The notion that the existence of the legal profession is so precarious that the state must intervene in the market to save the profession from perishing seems rather incredible. Even assuming some legitimate need for support, however, other approaches, such as subsidization or tax benefits, could achieve similar results for the profession without imposing licensure's restrictions on the client's choice of an advocate.

Only the fourth goal propounded for licensure systems, that of promoting client welfare, merits serious consideration. ${ }^{92}$ Defining client

(providing that nonlawyers may be admitted to practice on passing an examination). It is settled that the supremacy clause bars the states from prohibiting practice in federal forums by persons whom the federal government has expressly authorized to appear. See Sperry v. Florida ex rel. Fla. Bar, 373 U.S. 379, 385 (1963). It is possible that an overt federal attempt to regulate appearances before state tribunals would encounter an obstacle in the tenth amendment. But see Testa v. Katt, 330 U.S. 386 (1947). In practice, state-federal conflicts over admission to practice are infrequent. Perhaps owing to considerations of comity, most federal courts closely track the rules of the states in their jurisdiction. See, e.g., E.D. PA. R. Crv. P. 9(a):

Any attorney who has been admitted to and is authorized to practice in the .. . Supreme Court of Pennsylvania and is presently in good standing before such Court and who maintains an office in the Commonwealth of Pennsylvania for the regular practice of law may . . . make application to be admitted generally as an attorney of this Court.

92 Taking client welfare seriously as a goal does not mean taking it seriously as a description of the impulse behind existing unauthorized practice rules. The driving force behind these rules has never been any groundswell of consumer sentiment; it has always been the bar. For an insightful analysis of the competing professional interests involved, see Johnstone, The Unauthorized Practice Controversy, A Struggle Among Power Groups, 4 U. KaN. L. REv. 1 (1955).

Rhode's careful empirical work casts considerable doubt on the notion that consumer welfare represents the actual raison d'être of unauthorized practice provisions. See Rhode, supra note 1, at 6-44. A useful historical overview of the bar's role in the development of unauthorized practice doctrine appears in Christensen, supra note 11, at 161-97. Auerbach suggests that the development of bar requirements, ostensibly fur- 
welfare, however, remains a problem. The profession's position has been that client welfare is served when competent legal services are rendered. ${ }^{93}$ This definition fails to consider the costs of these services to the client and departs from one common American method for defining consumer well-being: deference to the free market. Any decision to intervene in the market on behalf of quality presupposes a market-independent definition of quality, ${ }^{94}$ as well as a specification of the class of services-legal, in this case-requiring regulation.

The current licensure system proceeds in rough-and-ready fashion by defining the practice of law as the class of things that lawyers commonly do and by positing that competence at what lawyers do will be fostered by attendance at the schools that produced the lawyers currently doing those things. ${ }^{95}$ An attempt to assess critically whether licensure actually protects client welfare, however, cannot begin by effectively assuming that it does. Accordingly, this Comment will proceed on the premise that the decisions a rational ${ }^{98}$ and informed consumer would make constitute the best measure of that consumer's welfare. This premise describes prevailing attitudes toward the market for the services of licensed practitioners. Given this measure, any intervention in the market for legal services can be justified only by reference to the client's irrationality or ignorance or by the possibility of harm to the interests of third parties.

Moreover, the Supreme Court has consistently identified the rights protected by the first amendment as fundamental to our form of government $^{97}$ and has subjected legislation affecting first amendment rights

thering client welfare, was motivated by a desire to exclude various ethnic groups from the profession. See J. Auerbach, UneQual Justice: LawYers and Social Change In Modern AMERICA 102-29 (1976).

9s For a critique of the bar's love affair with competence, see Garth, Rethinking the Legal Profession's Approach to Collective Self-Improvement: Competence and the Consumer Perspective, 1983 Wis. L. REv. 639.

*4 On the elusiveness of such a definition, see Carlson, Measuring the Quality of Legal Services: An Idea Whose Time Has Not Come, 11 Law \& Soc'y REv. 287 (1976).

9s See Rhode, supra note 1, at 45-47. Even this assumption may sometimes be questionable. In a New Haven study of uncontested divorces, pro se litigants did about as well as lawyers in form preparation and court proceedings. In some areas, such as timeliness in filing papers, the pro se litigants did better. See Project, The Unauthorized Practice of Law and Pro Se Divorce: An Empirical Analysis, 86 Y ALE L.J. 104, 12329 (1976).

of The word "rational" is used here to denote a tailoring of means to ends. This permits consideration of people who seek legal assistance for highly diverse reasons. Purely for reasons of expository economy, much of the discussion to follow deals with litigants whose primary interest is in maximizing net returns in the usual sense; however, the argument does not hinge upon this device.

or See supra note 39. 
to rigorous inquiry. "Substantial" furtherance of "compelling", state objectives has frequently been demanded, ${ }^{98}$ and the unavailability of "less drastic means"- of methods, that is, that would promote the legitimate purposes claimed for state legislation at a slighter cost to personal liberties-has often been explicitly identified as a criterion of constitutionality. ${ }^{\text {99 }}$

Although the less drastic means "test" has been criticized as vague $^{100}$ and although the Court has not explicitly pursued a less drastic means "analysis" in every first amendment case, the test provides a useful mechanism for analyzing the constitutionality of state regulations governing legal practice. Rules that infringe personal liberty to an unnecessarily draconian extent in light of their putatively legitimate purposes constitute precisely the paradigmatic mode in which state acts violate the Constitution. Because innumerable legal rules affect the ability of citizens to petition the courts, and because the petition rights at stake are central to the very preservation of a democratic social order, the question of less drastic means merits scrupulous attention.

Thus, even if licensure could be justified on the basis of promoting client welfare, it is rendered unconstitutional if less restrictive alternatives afford the same protection to clients. Section A of part III assesses the market impact of licensure on consumer welfare. Section B then compares the welfare of legal consumers under licensure and under a proposed certification scheme. The section concludes that certification protects consumer welfare as well as licensure and that licensure therefore represents an unconstitutionally drastic encroachment on litigants' first amendment rights. ${ }^{101}$

\section{A. The Effects of Licensure on the Market for Legal Services}

Licensure elevates prices insofar as it constricts supply. It con-

${ }^{83}$ E.g., NAAGP v. Button, 371 U.S. 415, 435-36 (1963).

9 See, e.g., NAACP v. Alabama, 377 U.S. 288, $307-08$ (1964); Shelton v. Tucker, 364 U.S. 479, 488 (1960); Martin v. Struthers, 319 U.S. 141, 146-49 (1941). (1969).

100 See, Note, Less Drastic Means and the First Amendment, 78 YAlE L.J. 464

${ }^{10 x}$ It is important not to confuse the two steps of this argument. Licensure implicates the petition clause by filtering the set of possible claims $P_{1}$ through the consciousness of lawyers before some proper subset $P_{2}$ of the claims reaches the courts' ears, possibly in distorted form. Licensure's defenders claim that it enhances client welfare. One must therefore ask whether this aim can rationally be associated with the existing structure of unauthorized practice provisions. It will transpire in the sequel that it cannot-at least not on the definition of welfare adopted here. Licensure harms welfare, by filtering the set of possible claimants $C_{1}$ through a cost sieve before some proper subset $C_{2}$ reaches the courtroom, possibly at too high a price. $P_{2}$ and $C_{2}$ are not coextensive. 
stricts supply insofar as it conditions market entry on meritocratic requirements. ${ }^{102}$ Meeting these requirements entails a positive cost that keeps some aspirants from competing, a cost borne in part by the clients of those who do compete. ${ }^{103}$

Licensure imposes a number of such meritocratic requirements affecting the supply and cost of legal services. These requirements include passing bar examinations, ${ }^{104}$ meeting moral character requirements, ${ }^{105}$ and achieving educational standards. The entry of would-be providers of legal services into the market is conditioned upon the fulfillment of licensure's requirements.

Educational requirements are probably the most formidable condition upon entry into the market for legal services. Most states require lawyers to complete three years of training at an accredited law school, and most such schools require a bachelor's degree as a condition for matriculation. It is difficult to estimate the degree to which these requirements function as absolute barriers; presumably, however, some persons are excluded. The educational requirements can be met only by persons in a position to gain admission to the appropriate institutions,

102 For a discussion of barriers to entry as they function in professional markets, see Moore, The Purpose of Licensing, 4 J.L. \& Econ. 93, 110-13 (1961).

10s Licensure also restricts the supply of legal services by creating human capital costs. Consider the case of educational requirements. If it is assumed that candidates defer $\$ 10,000$ in annual after-tax income for seven years, see infra note 106 , pay $\$ 4000$ per year in tuition, and spend another $\$ 2000$ on books and miscellaneous fees, then the total cost of preparing one unit of human capital in the legal profession is about $\$ 100,000$. If this sum were invested in a 40 -year annuity at seven percent interest, it would yield an annual income of $\$ 7519$, or about what a full-time employee would receive at the minimum wage.

104 Studies have found a significant correlation between bar examination failure rates and aggregate attorney income. See Holen, Effects of Professional Licensing Arrangements on Interstate Labor Mobility and Resource Allocation, $73 \mathrm{~J}$. Pol. EcoN. 492 (1965); Maurizi, Occupational Licensing and the Public Interest, $82 \mathrm{~J}$. PoL. Econ. 399 (1974). More recent students of the problem, employing different methods, have reached more ambiguous results. See Getz, Siegfried \& Calvani, Competition at the Bar: The Correlation Between the Bar Examination Pass Rate and the Profitability of Practice, 67 VA. L. REv. 863 (1981).

${ }_{108}$ Moral character requirements screen advocates by reason of their worldviews and thus foreclose selection of advocates able or willing to present formulations of legal claims that are generated by the excluded perspectives.

Potential implications of the use of such requirements are illustrated by their past uses. Auerbach describes the disbarment of attorneys who publicly criticized World War I and bar association attempts to exclude "unAmerican" candidates in order to safekeep "the moral qualities that underlie our American institutions." J. AUERBACH, supra note 92, at 103,106-123. Attorneys have also been excluded on the basis of their moral beliefs. See, e.g., In re Summers, 325 U.S. 516 (1944) (upholding Illinois's refusal to admit candidate to the bar because of his inability to take oath that the state interpreted as requiring willingness to serve in the militia, even though his refusal was due to religious beliefs). 
pay the tuition, and defer a substantial part of seven years' income. ${ }^{108}$ Such costs affect would-be consumers, as well as would-be providers, of legal services. Lawyers who desire a return on their educational investments may pass on their costs to consumers through their fees. ${ }^{107}$

The price of legal services affects consumer welfare by determining a level at which the costs of litigation exceed the probable award. Below this level, transactions are insufficiently valuable to litigate and fall outside the courts' protection. ${ }^{108}$ By raising fees to artificially high levels, licensure expands the class of such transactions, as well as increasing the litigation costs for transactions that are profitably pursued. As the table on the next page illustrates, consumers in each of three classes suffer a loss in welfare as a result. Parties currently appearing pro se are deprived of the chance to purchase services at certain levels of quality even if the increase in the size of the probable award that such services would effect more than offsets their cost. Parties currently proceeding with an attorney pay more than they would pay for the same services in the absence of licensure and are prevented from opting for lower levels of quality even if the decreased cost would more than compensate for the smaller probable award. A third class of persons, with claims of less than the threshold amount and for whom a pro se appearance is for some reason not a rational option, are entirely foreclosed from seeking the courts' protection, although in the absence of licensure some might rationally choose to purchase services at certain quality levels.

\section{B. The Certification Alternative}

The analysis in section A assumed that litigants possess sufficient information about the services they purchase to make them the best judges of their own best interests. Licensure, however, purports to re-

${ }^{108}$ It is appropriate to reckon the cost of the educational requirements by reference to seven years of education, rather than three years (or 19), for two reasons. First, the median level of educational attainment in the United States is 12.1 years-about seven years less than the general minimum for lawyers. See BUREAU OF THE Gensus, U.S. DeP'T OF Commerce, 1970 Census of Population, General Social and EConomic Characteristics: UNITED STATEs Summary I-361. Second, most states provide for (only) 12 years of education that are essentially costless to recipients.

${ }^{107}$ The effect on prices of human capital costs and entry barriers may not be cumulative. Entry barriers by themselves may escalate fees to a level sufficient to cause aspirants to pay the costs of education.

108 Such devices as class actions, where available, make this threshold lower than it would otherwise be. Nonlegal norms may also protect parties to transactions below the threshold. This threshold level, however, is still a primary consideration in any rational decision whether to litigate. 


\section{Expected Returns from Litigation}

with and Without Licensure for Selected

Risk-Neutral Claimants with Meritorious Claims

\begin{tabular}{c|l|c|c|c|c|c|c|c} 
Claimant & Advocate & $\begin{array}{c}\text { Value of } \\
\text { Claim }\end{array}$ & $\begin{array}{c}\text { Oppor- } \\
\text { tunity } \\
\text { Cost }\end{array}$ & Fee & $\begin{array}{c}\text { Probability of } \\
\text { Prevailing }\end{array}$ & $\begin{array}{c}\text { Expected } \\
\text { Award }\end{array}$ & $\begin{array}{c}\text { Net } \\
\text { Return }\end{array}$ & Litigate? \\
\hline A & Lawyer & 120 & -- & 80 & .750 & 90 & +10 & Yes \\
B & Lawyer & 100 & -- & 80 & .750 & 75 & -5 & No \\
C & Pro se & 100 & 40 & -- & .470 & 47 & +7 & Yes \\
D & Pro se & 100 & 50 & -- & .470 & 47 & -3 & No \\
E & Lawyer & 120 & -- & 55 & .750 & 90 & +35 & Yes \\
F & Lawyer & 100 & -- & 55 & .750 & 75 & +20 & Yes \\
G & Layperson & 100 &.- & 45 & .630 & 63 & +18 & Yes
\end{tabular}

The table above compares expected returns on litigation under licensure and in a hypothetical, deregulated world. It is assumed for simplicity's sake that the clients are risk neutral and possess meritorious claims of a definite value. It is also assumed that demand for practitioners' services, and therefore practitioners' fees, will vary with practioners' success rates in a properly functioning market.

Legal fees inevitably discourage litigation for certain claimants. See claimant $B$. Whether these claimants proceed without counsel depends partly on the opportunity costs (deferred income, for example) they would incur in doing so. Compare claimant $C$ with claimant $D$. If licensure's rescission lowered lawyers' fees by permitting competition from lay advocates, some claims currently excluded would make it to the courts. Compare claimants $B$ and $D$ with claimants $F$ and $G$. Moreover, claimants who already enjoy access would receive greater net returns. Compare claimant $A$ with claimant $E$, and claimant $C$ with claimants $F$ and $G$.

dress market failures caused by imperfections of consumer information in the actual world. Licensure's approach to information problems is to structure consumer choices so that even if consumers do not fully understand what they are buying, they can feel safe from the prospect of being led through ignorance to purchase services of a quality so poor as to compromise their interests. Although it may prevent a certain amount of damage to client interests, licensure diminishes consumer welfare as described in section $\mathrm{A}$.

A certification system could remedy information deficiencies without incurring the same disadvantages. Under a certification plan, the state-as well, perhaps, as private organizations such as malpractice insurers-would issue documents attesting that the recipient had attained a certain level of education, had passed an examination, or exhibited other objective indicia of legal competence. Practitioners would be prohibited from holding themselves out as possessing credentials they lacked and might be required to display their certificates (or to an- 
nounce their lack thereof) to prospective clients. No practitioner, however, would be prohibited from advising or representing clients without possessing a certificate. Clients would thus be free to select whatever counselor they chose. ${ }^{109}$

Some problems of consumer information will always exist in professions like law and medicine in which clients are unable to ascertain the nature and acuity of their problem without securing the diagnostic advice of an expert. One function of the malpractice system is to protect consumers from the untoward effects of misdiagnosis by deterring it and to compensate them on a post-event basis when it does occur. Malpractice, however, does not reduce the incidence of professional misfeasance to zero, and some forms of professional incompetence may so severely damage the consumer's interests that no post-event remedy could make her whole. In a profession where these effects are of substantial importance, licensure may be preferable to certification from the standpoint of public welfare despite the additional restrictions it imposes on consumer choice.

Medicine may be such a profession; the features of medical practice that may necessitate regulation by licensure, however, are not present in the practice of law. First, medical misdiagnosis and mistreatment may cause relatively minor problems to balloon into other problems of kinds and proportions that the consumer cannot foresee. This danger seems less significant in the legal context. Second, iatrogenic illness can be crippling or fatal. But apart from criminal cases, in which the Constitution affords a lawyer to most defendants who desire one, ${ }^{110}$ legal problems usually do not cause fatal or irreparable harm. A botched suit for money damages can be fully redressed after the fact by a malpractice suit for money damages; the arrival of the money is only delayed. Third, the level of medical treatment chosen by consumers acting individually may have undesirable effects on the health of others. For example, in a society where most persons receive immunization against contagious disease, some may opt for a free ride by foregoing immunization. If enough people chose this option, major epidemics

109 A growing literature extols the virtues and assesses the possible vices of certification as a regulatory method. See Christensen, supra note 11, at 213-16; Gellhorn, The Abuse of Occupational Licensing, 44 U. GHI. L. REv. 6, 26 (1976); Moore, supra note 102, at 104-06; Reich, Toward a New Consumer Protection, 128 U. PA. L. REv. 1, 35 (1979); Wolfson, Trebilcock \& Tuohy, Regulating the Professions, A Theoretical Framework, in OccuPational LICENSURE AND REgulation 180 (1980). For the classic exposition of the view that certification is virtually always a superior regulatory technique to licensing, see M. Friedman, Capitalism and Freedom 137-60 (1962).

${ }_{110}$ See Argersinger v. Hamlin, 407 U.S. 25 (1972) (no incarceration without representation). 
would break out. In contrast, legal problems are not contagious. On balance, the malpractice system seems to provide adequate protection against legal incompetence. ${ }^{111}$

Licensure, moreover, may create as many information problems in the legal services market as it solves. One of the variables that most effectively predicts whether persons with acute legal problems will seek legal advice is the extent of their past contact with members of the profession. Persons who have consulted attorneys before, or who have friends or relatives who are lawyers, are more likely to seek assistance than persons with little direct exposure to the profession. ${ }^{112}$ Yet licensure tends to restrict the number of both professional and private exposures. There is currently about one lawyer for every 500 American adults; ${ }^{113}$ if the number of practitioners were increased and their fees reduced, consumer contact and awareness might thereby be enhanced. This would be especially likely if competitive pressures led practitioners at different levels of expertise to broker information about their comparative success rates. ${ }^{114}$

In any event, certification would provide consumers with no less information than licensure. Any information conveyed to clients by virtue of a lawyer's possession of a license would still be conveyed if the license were transformed into a certificate that bestowed no exclusive right to practice. Certification thus represents a less restrictive alternative to licensure, rendering the latter an unconstitutional infringement of litigants' petition rights.

111 Problems associated with picking a standard of care for nonlawyer practitioners might be resolved by treating malpractice as a contractual breach, with a contractual damage measure. See Garth, supra note 93, at 676-78.

112 See Project, An Assessment of Alternative Strategies for Increasing Access to Legal Services, 90 YALE L.J. 122, 145 (1980).

113 This ratio has remained fairly constant throughout the century. See BuREAU of the Census, U.S. DeP'T OF Commerce, Historical Statistics of the UNITED STATES: Colonial TIMES to 1970 , at 15, 840 (1975).

114 The first amendment forbids at least some restrictions on advertising by lawyers. See In re R.M.J., 455 U.S. 191 (1982); Bates v. State Bar, 433 U.S. 350 (1977).

Regulations on advertising by lawyers implicate clients' ability to choose among advocates. This, in turn, touches upon the ability to present claims as the client envisions them. This is illustrated in Bishop v. Committee on Professional Ethics, $521 \mathrm{~F}$. Supp. 1219 (S.D. Iowa 1981). The plaintiff in Bishop was an attorney desiring to advertise his views on a variety of topics pertaining to delivery of legal services. He also wished to advertise the fact that his associate was black. The court rejected his arguments regarding expression of his views on legal services because they were not "statements of verifiable fact." In response to the advertising of his associate's race, the court approved the factual nature of the information and noted, "many persons, . . . are apprehensive about going to a lawyer and prefer . . . to seek out a lawyer with whom they can identify. (This court has encountered black litigants in need of court appointed counsel who felt that they could effectively communicate with and trust only a black lawyer.)" Id. at 1226. 


\section{Concluston}

Licensure implicates the petition clause by filtering the set of all possible legal claims through the consciousness of lawyers before some subset of those claims reaches the court's ears in modified form. Licensure also filters the set of possible claimants through a cost sieve before some subset of those claimants reaches the courtroom, possibly at too high a price. These filtering processes constrain the sweep of the discursive process that is crucial to the legitimation of government.

The first amendment teaches that the right to petition inheres in the citizen and does not await state authorization; it may be restricted only to the extent necessary to further important state purposes. Here, the purported state purpose of promoting client welfare is in fact hindered, rather than enhanced, by licensure. Licensure restricts consumer choice and thereby impedes access to the courts, both by requirements imposed upon would-be advocates and costs imposed upon would-be consumers.

Certification offers a less restrictive and more efficacious means of promoting client welfare. No rational client would opt for a scheme in which legal costs are superfluously high and the chance to invoke the judicial system to protect one's interests is sometimes unnecessarily denied. The existence of a less restrictive means to promote client welfare, in a context implicating the petition right, renders licensure constitutionally impermissible and serves to undermine the legitimacy of our legal system by erecting a barrier between the judiciary and the citizenry. The legislatures, therefore, should repeal it; the courts, overrule it. Failing that, the legal profession should reflect on whether its monopoly on advocacy really conduces to the health of the Republic. 
, 